ఠ

ERRATUM

\title{
Patterns and predictors of long-term retention of inflammatory bowel or rheumatoid disease patients on innovator infliximab: an analysis of a Canadian prescriptions claims database [Erratum]
}

BaerPA, Aumais G, Ewara EM, etal.Patient Prefer Adherence. 2018;12:1805-1814.

On page 1805 , the affiliations were incorrectly listed. The correct affiliations should be as follows:

Philip A Baer ${ }^{1}$

Guy Aumais ${ }^{2}$

Emmanuel M Ewara ${ }^{3}$

Majed Khraishi ${ }^{4}$

A Marilise Marrache

Remo Panaccione 6

John P Wade ${ }^{7}$

John K Marshall ${ }^{8}$
${ }^{1}$ Baer Weinberg MPC, Scarborough, ON, ${ }^{2}$ Department of Medicine, Université de Montréal, Gastro-enterology Unit, Hôpital Maisonneuve-Rosemont, Montréal, QC, ${ }^{3}$ Government Affairs and Market Access, Janssen Inc., Toronto, ON, ${ }^{4}$ Faculty of Medicine, Division of Rheumatology, Memorial University of Newfoundland and Nexus Clinical Research, St John's, NL, ${ }^{5}$ Medical Affairs, Janssen Inc., Toronto, ON, ${ }^{6}$ Inflammatory Bowel Disease Unit, Department of Medicine, University of Calgary, Calgary, AB, ${ }^{7}$ Department of Medicine, Division of Rheumatology, University of British Columbia, Vancouver, BC, ${ }^{8}$ Department of Medicine, Division of Gastroenterology, McMaster University and Farncombe Family Digestive Health Research Institute, Hamilton, ON, Canada
Patient Preference and Adherence

\section{Publish your work in this journal}

Patient Preference and Adherence is an international, peer-reviewed, open access journal that focuses on the growing importance of patient preference and adherence throughout the therapeutic continuum. Patient satisfaction, acceptability, quality of life, compliance, persistence and their role in developing new therapeutic modalities and compounds to optimize

\section{Dovepress}

clinical outcomes for existing disease states are major areas of interest for the journal. This journal has been accepted for indexing on PubMed Central. The manuscript management system is completely online and includes a very quick and fair peer-review system, which is all easy to use. Visit http://www. dovepress.com/testimonials.php to read real quotes from published authors. 